\title{
Effect of different drying techniques on quality characteristics of African palmyra palm (Borassus aethiopum) fruit flour
}

\author{
${ }^{1}$ Abe-Inge, V., ${ }^{1 *}$ Agbenorhevi, J.K., ${ }^{2}$ Kpodo, F.M. and ${ }^{3}$ Adzinyo, O.A. \\ ${ }^{1}$ Department of Food Science and Technology, Kwame Nkrumah University of Science and Technology, \\ Kumasi, Ghana \\ ${ }^{2}$ Department of Nutrition and Dietetics, University of Health and Allied Sciences, Ho, Ghana \\ ${ }^{3}$ Department of Hospitality and Tourism Management, Ho Technical University, Ho
}

\section{Article history:}

Received: 20 February 2018

Received in revised form: 14 March 2018

Accepted: 15 March 2018

Available Online: 6 April 2018

\section{Keywords:}

Borassus aethiopum,

Underutilized plants,

Flour,

Food applications

\section{DOI:}

https://doi.org/10.26656/fr.2017.2(4).050

\begin{abstract}
African palmyra palm (Borassus aethiopum Mart.) fruits are underutilized in Sub-Saharan Africa. The objective of this study was to produce flour from the African palmyra palm (APP) fruit pulp and evaluate the effect of different drying methods on the quality characteristics of the flour. The fresh pulp was oven, solar, and freeze-dried. Proximate, physicochemical and functional properties of the flours were determined. The flours had high amount of crude fibre (14.04-19.52\%), carbohydrates (64.56-73.60\%), energy $(281.92-73.60 \mathrm{kCal} / 100 \mathrm{~g})$, relatively high water absorption capacity $(307.18-517.66 \%)$, swelling power (433.0-556.92\%), oil absorption capacity (83.48-164.38\%) and good flowability (Hausner Ratios below 1.4 and Carr's Indices below 23\%). The present findings show that APP flour could be used as a potential ingredient in various food products such as pasta, puddings, cakes, biscuits, bread, crackers and doughnuts.
\end{abstract}

\section{Introduction}

African palmyra palm (Borassus aethiopum) is a member of the family Arecaceae and grows in the wild across Africa. The palmyra palm bears fruits massively (between 50-150 fruits per tree) in every 8 months (Ali et al., 2010; Ouinsavi et al., 2011). However, only about 30 $-40 \%$ of these available nutritious fruits are utilized as food (Ali et al., 2010; Siaw et al., 2014). The remaining 60 to $70 \%$ undergo losses via microbial decomposition. Losses of the African palmyra palm fruits greatly results from limited diversification of utilization as well as poor storage conditions. The fresh fruit pulp is hand mashed, filtered and eaten raw or boiled with corn or porridge mostly in the rural areas of Africa (Sambou et al., 1992; Ali et al., 2010; Siaw et al., 2014; Adzinyo et al., 2015). African palmyra palm fruit pulp as an accompaniment to foods is known to impart natural sweetness, aroma, and color (Adzinyo et al., 2015). Fresh African palmyra palm fruit pulp is a rich source of minerals, fiber, sugars, vitamin A, vitamin C and moisture (Ali et al., 2010). This nutritious nature coupled with the high moisture of the palmyra palm fruits limits the postharvest life via microbial spoilage which eventually leads to its wastage in season. Drying which is one of the oldest and most suitable methods of food preservation in tropical Africa could be employed as a preservation method to reduce the moisture content of African palmyra palm fruit pulp to levels least likely to support the growth of spoilage microorganisms. Although drying affects the nutritional composition and bioactive compounds of fruits (Rahman, 2005; Di Scala and Crapiste, 2008), it has been successfully employed in the production of flour from plantain, banana, pumpkin, tomato, and pepper. This was achieved through appropriate selection of drying temperature, time and methods. Oven drying and freezedrying have been successfully employed to produce flour with sufficient nutrient composition and quality from ackee arils and soursop (Dossou et al., 2014; Lombor, 2014).

The appropriate and successful incorporation of flour into food systems is dependent on the physicochemical, functional and nutritional composition. Hence the proximate composition, functional properties such as water binding capacity, foaming properties and swelling power of flours are usually analyzed to predict their appropriate incorporations and explorable applications in food systems. This research was aimed at producing African palmyra palm fruit flour and evaluating the effect of different drying methods on the quality characteristics of the flour. 


\section{Materials and methods}

\subsection{Materials and sample preparation}

Fresh African palmyra palm (Borassus aethiopum) fruits were obtained from Adaklu in the Volta region of Ghana. The fruits were washed and weighed after calyx removal. The epicarp of the fruits was carefully peeled off, pulp (mesocarp) separated and weighed using the electronic balance (Mettler Toledo, Switzerland). The obtained pulp $(1.64 \mathrm{~kg})$ was divided into four portions. A portion was solar dried for $14 \mathrm{~h}$ at temperatures between $30-36^{\circ} \mathrm{C}$ using the tunnel solar drier. The second and third portions were freeze-dried (at $-47^{\circ} \mathrm{C}$ to $-55^{\circ} \mathrm{C}$, 0.002 to 2.7 Torr) for $72 \mathrm{~h}$ using the vacuum freeze dryer (model: YK-118-50, Taiwan) and oven dried at $60^{\circ} \mathrm{C}$ for $6 \mathrm{~h}$ using the hot air oven (Binder Heating and Drying Oven, Tuttlingen, Germany) respectively. Drying continued until the moisture content of the samples reduced to values below $10 \%$. The fourth portion was used as the experimental control in the proximate analysis. The dried samples were milled to particle sizes of $450 \mu \mathrm{m}$, packaged in zip-lock bags and stored at $-20^{\circ}$ $\mathrm{C}$ in a freezer (Protech PRCF-500, China) for further analysis. Between 150- $230 \mathrm{~g}$ of dried flour was obtained with an estimated quantity of $50 \mathrm{~g}$ used for the various analysis.

\subsection{Proximate composition of flour samples}

Proximate analysis was done on the different African palmyra palm (Borassus aethiopum) fruit flour samples. Moisture, protein, ash, crude fat and crude fibre were determined according to AOAC (1990). Protein was calculated from total nitrogen using the conversion factor 6.25. Carbohydrate was determined by difference. Calculated Metabolic Energy (CME) was determined for the different flour samples.

\subsection{Functional and physicochemical properties of the flour samples}

\subsubsection{Water and oil absorption capacities}

Water and oil absorption capacities of the flour samples were determined (Chandra and Samsher, 2013) and calculated using the equations:

$$
\begin{aligned}
& \text { WAC } \%=\frac{\text { Weight of absorbed water }}{\text { Weight of flour }} \times 100 \% \\
& \text { OAC } \%=\frac{\text { Weight of absorbed oil }}{\text { Weight of flour }} \times 100 \%
\end{aligned}
$$

\subsubsection{Swelling power and solubility}

The swelling power and solubility of the flours were determined according to Dossou et al. (2014) with modifications. The swelling power and the solubility of the flour samples were calculated as follows:

$$
\begin{aligned}
& \% \text { Swelling Power }=\frac{\text { Weight of paste }}{\text { Weight of sample }} \times 100 \% \\
& \% \text { Solubility }=\frac{\text { Weight of soluble fraction }}{\text { Weight of sample }} \times 100 \%
\end{aligned}
$$

\subsubsection{Foaming capacity}

The foaming capacity of the flour samples was determined (Yellavila et al., 2015) and calculated using the equation:

$\%$ Foaming Capacity $=\frac{\text { Volume of foam }}{\text { Volume of initial mixture }} \times 100 \%$

\subsubsection{Determination of $\mathrm{pH}$ and total soluble solids}

The $\mathrm{pH}$ and the total soluble solids (TSS) of the flour samples were determined using $10 \%$ aqueous solution of each flour. The $\mathrm{pH}$ was measured using a calibrated $\mathrm{pH}$ meter (Seven Compact pH/ion S220, Mettler Toledo AG, Switzerland) whilst the total soluble solids (TSS) content was determined using a refractometer.

\subsection{Determination of bulk properties}

\subsubsection{Bulk density}

Bulk density was determined according to the method of Dossou et al. (2014). The Hausner ratios and Carr's Indices of the flour samples were calculated according to Wijesinghe et al. (2015). Hausner ratio was determined as a ratio of the tapped bulk density to the loose bulk density of the flour.

\subsection{Statistical analysis}

Data were reported as averages of triplicate and analyzed using one-way analysis of variance (ANOVA) to compare the means of all determined parameters. Tukey's test at 5\% level of significance was used to determine significant differences among samples.

\section{Results and discussion}

The African palmyra palm fruit flours appeared as shown in Figure 1. A high degree of browning occurred in the solar dried flour, whereas virtually no browning occurred in the freeze-dried flour. The rate of both enzymatic and non-enzymatic browning reactions increase during drying especially under favourable conditions of adequate moisture, temperature and the presence of air (Wiriya et al., 2009). These reactions eventually lead to oxidative bleaching via the formation of brown pigments (melanoidins) and degradation of the original pigments of the food materials. The brown color of the solar dried flour could, therefore, be associated with these changes.

\subsection{Proximate composition of African palmyra palm flour}



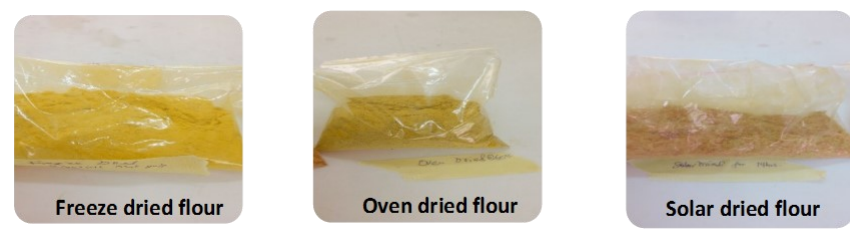

Figure 1. Images of differently dried flour products

The moisture content of the flour samples ranged from 4.01 to $7.61 \%$ with freeze-dried flour recording the lowest moisture whilst the solar dried flour recorded the highest (Table 1). The moisture content of flour samples was lower than values reported in the literature for cassava flour (8-11\%) and wheat flour (12-13\%) (Dziedzoave et al., 2006; Eriksson, 2013; Chandra and Shamsher, 2013). Food products with high moisture content are susceptible to microbial attack as well as spoilage and therefore have limited shelf life (Hassan and Umar, 2004). Hence the low moisture content of the flour samples indicates their stability against microbial attack and potential longer shelf life.

The ash content of a food product is an indication of its mineral content, safety, and quality. The ash content of the African palmyra palm fruit flour ranged from $2.51 \%$ (freeze-dried flour) to $4.14 \%$ (oven-dried flour) (Table 1). However, all the flour samples had higher ash than the fresh fruit pulp $(0.90 \%)$. The fresh pulp ash content was slightly higher than the value $(0.73-0.74 \%)$ reported for the palmyra palm fruit obtained from Cameroon (Ali et al., 2010). The oven and solar dried flour samples contained higher ash than the young germinating shoots of the palmyra palm $(1.17 \%)$, yam flour $(1.66-3.28 \%)$, refined wheat flour $(1.40 \%)$ and maize flour (1.09\%) (Leach et al., 1959; Udensi et al., 2008; Ezeocha and Ojimelukwe, 2012; Senanayake et al., 2012; Oppong et al., 2015; Umar et al., 2015; Ezeokeke and Onuoha, 2016). The African palmyra palm fruit flour can, therefore, be used to improve the mineral content of both wheat and maize flours as well as their products.

Fat contributes to the total energy content of a food product. Hence its value is important in estimating the caloric value of a food product. The fat content of the flour samples ranged from 1.15 to $3.44 \%$ (Table 1). The solar dried flour sample recorded the least crude fat content $(1.15 \%)$ whilst the oven dried flour sample recorded the highest crude fat content $(3.44 \%)$. The fresh fruit pulp recorded a crude fat content of $0.15 \%$. The low crude fat content recorded for the fresh sample could be due to the high moisture (69\%) of the fresh pulp. Moisture which is polar in nature might have interfered with the solvent extraction process. The crude fat contents of the freeze-dried and oven dried flours were higher than the edible hypocotyls of palmyra palm (0.01\%) and wheat flour (Leach et al., 1959; Akpapunam and Sefa-Dedeh, 1997; Oppong et al., 2015; Umar et al., 2015). The low fat content of the flours indicates their stability against rancidity via lipolytic reactions hence an enhanced shelf stability.

The crude protein content of the flour samples ranged from 2.54 to $3.33 \%$ (Table 1), with the freezedried sample recording the least value (2.54\%) whilst the solar dried flour sample recorded the highest protein content $(3.33 \%)$. However, all the three flour samples had higher protein content than the fresh pulp $(0.83 \%)$. The crude protein of the palmyra palm fruit flour studied was lower than values reported in literature for wheat flour (10.23-14.70\%), yellow maize flour (4.99\%), white maize flour (5.56\%) and millet flour (6.44\%) (Morris et al., 1999; Adams et al., 2002; N'guessan et al., 2014; Oppong et al., 2015). However, the crude protein of the African palmyra palm flours was comparable to values obtained for banana flour (2.78\%) (Ezeokeke and Onuoha, 2016), and higher than values obtained in cassava flour (0.56-1.26\%) (Maziya-Dixon et al., 2015). The African Palmyra palm fruit flour is generally low in protein content.

The freeze-dried flour samples had the lowest crude fibre content $(14.00 \%)$ whilst the solar dried flour had the highest value (19.52\%) (Table 1). The flour samples, however, had a lower fibre content in comparison to the fresh pulp (20.21\%). The fruit flour contains higher fibre than maize flour $(0.20-0.85 \%)$, banana flour $(0.11$ -

Table 1. Proximate composition of African palmyra palm (APP) fruit flour

\begin{tabular}{lcccc}
\hline \multicolumn{1}{c}{ Parameter } & Freeze-dried flour & Oven dried flour & Solar dried flour & Fresh fruit pulp \\
\hline Moisture (\%) & $4.01 \pm 0.06^{\mathrm{a}}$ & $4.68 \pm 0.09^{\mathrm{a}}$ & $7.61 \pm 0.14^{\mathrm{b}}$ & $69.00 \pm 0.34^{\mathrm{c}}$ \\
Ash (\%) & $2.51 \pm 0.05^{\mathrm{a}}$ & $4.14 \pm 0.11^{\mathrm{b}}$ & $3.83 \pm 0.01^{\mathrm{b}}$ & $0.90 \pm 0.13^{\mathrm{c}}$ \\
Crude Fat (\%) & $3.30 \pm 0.38^{\mathrm{a}}$ & $3.44 \pm 0.95^{\mathrm{a}}$ & $1.15 \pm 0.00^{\mathrm{b}}$ & $0.15 \pm 0.01^{\mathrm{b}}$ \\
Crude Protein (\%) & $2.54 \pm 0.07^{\mathrm{a}}$ & $3.13 \pm 0.06^{\mathrm{b}}$ & $3.33 \pm 0.00^{\mathrm{b}}$ & $0.83 \pm 0.06^{\mathrm{c}}$ \\
Crude Fibre (\%) & $14.04 \pm 0.06^{\mathrm{a}}$ & $18.02 \pm 0.46^{\mathrm{b}}$ & $19.52 \pm 0.97^{\mathrm{b}}$ & $20.21 \pm 0.01^{\mathrm{b}}$ \\
CHO (\%) & $73.60 \pm 0.28^{\mathrm{a}}$ & $66.59 \pm 0.45^{\mathrm{b}}$ & $64.56 \pm 1.11^{\mathrm{b}}$ & $8.91 \pm 0.15^{\mathrm{c}}$ \\
CME (kCal /100g) & $334.25 \pm 2.58^{\mathrm{a}}$ & $309.79 \pm 6.50^{\mathrm{b}}$ & $281.92 \pm 4.38^{\mathrm{c}}$ & $40.31 \pm 0.74^{\mathrm{d}}$ \\
\hline
\end{tabular}

Values represent mean \pm SD of at least three replicates. Means in the same row with the same superscript are not significantly different $(\mathrm{p}>0.05) . \mathrm{CHO}=$ Available Carbohydrate; $\mathrm{CME}=$ Calculated Metabolic Energy 
$3.50 \%)$, soybean flour $(0.88 \%)$, millet flour (0.27$2.70 \%$ ), ackee fruit aril flour (3.83-4.08\%), wheat flour $(0.36-0.82 \%)$ and cassava flour (1.48-1.54\%) (Adebowale et al., 2011; N'guessan et al., 2014; Dossou et al., 2014; Oppong et al., 2015; Heshe et al., 2015; Ezeokeke and Onuoha, 2016). Dietary fibre is good for preventing or controlling diabetes, cardiovascular diseases, obesity, and cholesterol levels. Dietary fibre lowers cholesterol levels in the body by interfering with its absorption (Mehta and Kaur, 1992; Pereira, 2004). As a prebiotic, dietary fibre also helps maintain the intestinal microflora hence contributes to keeping a healthy gut system. The intestinal bacteria convert dietary fibre into short chain fatty acids such as acetate, propionate, and butyrate via their catabolic activities (Wong et al., 2006). The intestinal microflora utilizes these short chain fatty acids for chemical energy to carry out their biological processes. The RDA for dietary fibre intake is $18-35 \mathrm{~g}$ per day depending on the age and gender of the individual (Mohammed et al., 2011). The palmyra palm flour samples may meet this recommendation when consumed appropriately. Dietary fibre also gives a feeling of satiety, therefore, the flours could be applied in the production of lower glycaemic index foods for Type-II diabetics.

The available carbohydrates of the flour samples ranged from 64.56 to $73.60 \%$ and are higher than the fresh fruit pulp (8.91\%) (Table 1). The freeze-dried samples recorded the highest value whilst the solar dried samples recorded the least available carbohydrate value. The available carbohydrate contents of the African Palmyra palm fruit flours were lower compared to banana flour (76.68\%), maize flour (71.87-85.64\%), cassava flour (75.50-75.90\%) and millet flour $(89.19 \%)$ but higher than the available carbohydrate content of soya bean flour $(26.14 \%)$, cowpea flour $(57.35 \%)$ and defatted ackee aril flour (39.58-42.48\%) (Adebowale et al., 2011; Dossou et al., 2014; N'guessan et al., 2014; Oppong et al., 2015; Ezeokeke and Onuoha, 2016). The relatively higher carbohydrate content indicate that the flour samples are a good source of energy for the body. Hence, dieticians could recommend the application of the flours in energy foods. Carbohydrates also play a role in the functional properties of the flour samples by associating with water molecules via hydrogen bonding which results in water absorption and swelling (Fennema, 1996). Hence the flours could serve as humectants and thickeners in food products.

\subsection{Calculated metabolic energy}

The metabolic energy of the African palmyra palm fruit flours ranged from 334.25 to $281.93 \mathrm{kCal} / 100 \mathrm{~g}$ whilst the fresh fruit pulp recorded a comparatively lower value of $40.31 \mathrm{kCal} / 100 \mathrm{~g}$ (Table 1 ). The lower energy content of the fresh pulp could be attributed to its high moisture (69.00\%) and crude fibre (20.21\%) contents. The caloric values of all the flours were lower as compared to soya bean flour $(458.58-473.62 \mathrm{kCal})$ (Eshun, 2012). The CME value of the freeze-dried flour was comparable to ackee aril flour (327.61-645.43 kCal) (Dossou et al., 2014).

\subsection{Functional and physicochemical properties of African palmyra palm fruit flour}

3.3.1 Water absorption capacity, swelling capacity and solubility index

The water absorption capacity (WAC) of the APP fruit flour ranged from $307.18 \%$ in the solar dried flour to $517.66 \%$ in the freeze-dried flour (Table 2). The WAC of the freeze-dried flour was significantly higher $(\mathrm{p}<$ $0.05)$ than the WAC of the oven and solar dried flours. Water absorption capacity is reported to be a function of hydrophilic molecules (mainly proteins and carbohydrates) hence correlates positively with the amount of these molecules in the food material (Fennema, 1996; Dossou et al., 2014). Therefore, the high WAC (517.66\%) for the freeze-dried APP fruit flour in this study could be attributed to its high carbohydrate content $(73.60 \%)$. A similar trend was observed for the solar dried and oven dried flours.

The water absorption capacity of the APP flours were higher than values obtained for plantain (284\%), cassava flour (170-175\%) and wheat flour $(65-170 \%)$ (Mepba et al., 2007; Eleazu et al., 2014), but lower than the WAC in defatted ackee aril flour (565.53 - 982.88\%) (Dossou et al., 2014). Flours with high water absorption capacities can be recommended as a humectant in food products such as cakes, bread, and pastries.

Table 2. Functional properties of African palmyra palm fruit flour

\begin{tabular}{lccc}
\hline \multicolumn{1}{c}{ Parameter } & $\begin{array}{c}\text { Freeze- } \\
\text { dried flour }\end{array}$ & $\begin{array}{c}\text { Oven dried } \\
\text { flour }\end{array}$ & $\begin{array}{c}\text { Solar dried } \\
\text { flour }\end{array}$ \\
\hline Swelling & $556.92 \pm$ & $433.06 \pm$ & $433.00 \pm$ \\
capacity (\%) & $2.81^{\mathrm{a}}$ & $5.81^{\mathrm{b}}$ & $11.02^{\mathrm{b}}$ \\
Solubility Index & $14.08 \pm$ & $33.41 \pm$ & $33.02 \pm$ \\
$(\%)$ & $0.63^{\mathrm{a}}$ & $0.29^{\mathrm{b}}$ & $2.48^{\mathrm{b}}$ \\
WAC (\%) & $517.66 \pm$ & $324.62 \pm$ & $307.18 \pm$ \\
& $1.48^{\mathrm{a}}$ & $5.72^{\mathrm{b}}$ & $2.63^{\mathrm{c}}$ \\
OAC (\%) & $164.38 \pm$ & $83.48 \pm$ & $109.10 \pm$ \\
& $0.06^{\mathrm{a}}$ & $0.66^{\mathrm{b}}$ & $0.77^{\mathrm{c}}$ \\
Foaming & $23.5 \pm$ & $2.00 \pm$ & $2.04 \pm$ \\
capacity (\%) & $2.12^{\mathrm{a}}$ & $0.06^{\mathrm{b}}$ & $0.06^{\mathrm{b}}$ \\
\hline
\end{tabular}

Values represent mean \pm SD of at least three replicates of replicates. Means in the same row with the same superscript are not significantly different $(\mathrm{p}>0.05)$. WAC $=$ Water Absorption Capacity; OAC $=$ Oil Absorption Capacity 
Water absorption capacity is associated with swelling capacity since they both are functions of proteins and carbohydrates. The proteins and carbohydrates associate with water molecules via the formation of hydrophilic bonds (Dossou et al., 2014). This accounts for the swelling power trend in the APP flours in this study. The freeze-dried flour had a significantly $(p<0.05)$ higher swelling power $(556.92 \%)$ than the oven-dried flour $(433.06 \%)$ and solar dried flour (433.00\%). The high swelling powers of the APP flours could be attributed to their relatively high carbohydrate and crude fibre content which have the ability to absorb water molecules and swell. The presence of strong attractive forces within the structures of these molecules results in swelling as water is absorbed leading to an increased viscosity of the medium.

Flours with high swelling capacity as well as water absorption capacity are recommended as functional ingredients in the production of viscous foods like baked products, dough, pasta and food gels (Fennema, 1996). Flours that are suitable for good quality functional ingredients have low solubility and high swelling capacity. The freeze-dried flour samples with the highest swelling capacity (556.92\%) recorded the least solubility index $(14.08 \%)$ whilst the oven dried flour recorded the highest solubility index (33.41\%). The high solubility of the oven dried and solar dried flours could be due to increased hydrophilicity caused by an increase in the polar components (sugars, organic acids, and soluble proteins) as a result of processing methods. High solubility could also be attributed to weak forces of attraction between the molecules of food material leading to an increased dissolution of the food material in water (Dossou et al., 2014).

\subsubsection{Oil absorption capacity}

The oil absorption capacity (OAC) of food ingredients could be used as a measure of the flavor retention ability of the flours. It is also a measure of the amount of oil absorbed by the food material during cooking (Adebowale et al., 2011). The oil absorption capacity (OAC) of the APP fruit flours ranged from $83.48 \%$ in the oven dried flour to $164.38 \%$ in the freezedried flour (Table 2). There was a significant difference $(p<0.05)$ among all the three flours. The freeze-dried APP fruit flour had higher OAC than plantain flour $(130 \%)$, wheat flour $(110 \%)$ and cassava flour (61.5072.50\%) (Mepba et al., 2007; Adebowale et al., 2011).

Fats and oils are important in food systems since they contribute to the organoleptic properties (mouthfeel, aroma, appearance, smoothness, creaminess) of food products (Borja et al., 2013). Food ingredients with high oil absorption capacities are therefore suitable as lipid- based functional ingredients in food products such as doughnuts, cookies, crackers and meat products (Fennema, 1996; Chandra and Shamsher, 2013). The African palmyra palm fruit flours especially the freezedried and oven-dried flours could, therefore, be applicable in these food products.

\subsubsection{Foaming capacity}

The foaming capacity of the APP flours ranged from $2.00 \%$ in the oven dried flour to $23.5 \%$ in the freezedried flour (Table 2). The trend is similar to that of OAC in this study. The foaming capacity of freeze-dried flour is higher than the foamability of cassava flour (1.48$3.73 \%$ ) but lower than wheat flour (28.89\%) (Adebowale et al., 2011; Borja et al., 2013). Foaming capacity is important for assessing the suitability of incorporating a food ingredient into a food system. Food products such as cakes, sponges, ice creams, marshmallows, whipped creams, and bread require food ingredients with high foaming capacity (Fennema, 1996; Atuonwu and Akobundu, 2010). However, food ingredients with low foaming capacity are suitably applied in biscuits, crackers, and cookies (Borja et al., 2013). The APP flours could, therefore, be utilized in biscuits, crackers and cookies production due to their relatively low foaming capacity.

\subsection{Physicochemical properties of African palmyra palm fruit flour}

\subsection{1 $\mathrm{pH}$ and Titratable acidity}

The $\mathrm{pH}$ is a measure of active acidity whilst titratable acidity is an estimate of the total acid concentration in a food sample (Nielsen, 2010). The $\mathrm{pH}$ of the APP flours ranged from 4.11 to 4.26 (Table 3 ). The oven dried flours had the lowest $\mathrm{pH}$ whilst the solar dried flour had the highest $\mathrm{pH}$. The lower $\mathrm{pH}$ and moisture content of the African palmyra palm fruit flours could be an indication of shelf stability against microbial contamination.

The low $\mathrm{pH}$ also correlates with the titratable acidity of the flour samples which ranged from $1.59 \%$ in the solar dried flour to $2.11 \%$ in the oven dried flour (Table $3)$. These values for the APP flours are significantly higher than the titratable acidity for cassava flour and wheat flour (0.36-0.45\%) (Eriksson, 2013).

\subsubsection{Total soluble solids}

The total soluble solids of the APP fruit flours were found to be statistically similar. The values ranged from $4.46 \%$ in the solar dried flour to $4.66 \%$ in the freezedried flour (Table 3). The total soluble solids, which is an indication of the total sugar concentration in the flour, 
coupled with the $\mathrm{pH}$ and titratable acidity are important for the processing, storage, and quality of food produced with the APP flour. These parameters also play a significant role in the functional properties and application of the food ingredient (Apea-Bah, 2011).

Table 3. Physicochemical properties of African palmyra palm fruit flour

\begin{tabular}{lccc}
\hline Parameter & $\begin{array}{c}\text { Freeze-dried } \\
\text { flour }\end{array}$ & $\begin{array}{c}\text { Oven dried } \\
\text { flour }\end{array}$ & $\begin{array}{c}\text { Solar dried } \\
\text { flour }\end{array}$ \\
\hline pH & $4.12 \pm 0.01^{\mathrm{a}}$ & $4.11 \pm 0.01^{\mathrm{a}}$ & $4.26 \pm 0.01^{\mathrm{b}}$ \\
TTA $(\%)$ & $1.84 \pm 0.04^{\mathrm{a}}$ & $2.11 \pm 0.02^{\mathrm{b}}$ & $1.59 \pm 0.00^{\mathrm{c}}$ \\
TSS $\left({ }^{\circ}\right.$ Brix $)$ & $4.66 \pm 0.15^{\mathrm{a}}$ & $4.60 \pm 0.00^{\mathrm{a}}$ & $4.46 \pm 0.06^{\mathrm{a}}$ \\
\hline
\end{tabular}

Values represent mean \pm SD of at least three replicates. Means in the same row with the same superscript are not significantly different $(\mathrm{p}>0.05)$. TTA $=$ Titratable Acidity; TSS $=$ Total Soluble Solids.

\subsubsection{Bulk densities of African palmyra palm fruit} flour

The loose bulk density of the APP flours ranged from $0.36 \mathrm{~g} \mathrm{ml}^{-1}$ in the freeze-dried flour to $0.63 \mathrm{~g} \mathrm{ml}^{-1}$ in the oven dried flour. The trend of the loose bulk density was similar to the trend of the tapped bulk densities which also ranged from 0.46-0.77 $\mathrm{g} \mathrm{ml}^{-1}$ (Table 4). However, the tapped bulk densities were higher than their corresponding loose bulk densities. The bulk densities of the APP flours are lower than that of cowpea flour (0.82 $\left.\mathrm{g} \mathrm{ml}^{-1}\right)$ (Oppong et al., 2015) and soya bean flour (1.56-2.09 $\mathrm{g} \mathrm{ml}^{-1}$ ) (Eshun, 2012). However, values in this study are comparable to values obtained for ackee aril flour and wheat flour (Dossou et al., 2014; Oppong et al., 2015).

An increase in the bulk densities after tapping could be attributed to the porosity of the flour samples which causes a decrease in the sample volume after tapping. Therefore, the higher bulk densities in the oven dried flours are advantageous since larger flour quantities can be contained in smaller packages. A factor that contributes to variation in the bulk densities of flours has been observed to be particle size and shape (Appiah et al., 2011). The porosity of the flour also causes variation in bulk density where highly porous flours usually have lower bulk densities. Freeze-dried flour has a relatively higher porosity hence have lower bulk density compared to flours produced from other drying methods (Krokida and Maroulis, 1997). Low bulk density flours are suitably applied in complementary foods (Akpata and Akubor, 1999).

\subsubsection{Hausner ratio and Carr's index}

Hausner ratios of APP flours ranged from 1.19 in the solar dried flour to 1.27 in the freeze-dried flour (Table 4). The Carr's Indices also ranged from $15.79-21.43 \%$ and followed a similar trend (Table 4). Hausner ratio and Carr's Index are measures of the flowability and compressibility (porosity) of flours (Muazu et al., 2011). Flours with Hausner Ratio below 1.4 and Carr's Index below $23 \%$ are said to have good flow properties (Barbosa-Canovas et al., 2005; Ogunsina et al., 2010; Wigesinghe et al., 2015). This implies the APP flours had good flow properties and compressibility. The Hausner ratios and Carr's Index values in this study were comparable to that of ackee aril flour and Kithul flour (Dossou et al., 2014; Wigesinghe et al., 2015). Flours with good flowability are suitable for easier mixing, transport, and other manufacturing processes. Therefore, APP flours have potential applications in a number of industrial food processing.

Table 4. Bulk properties of African palmyra palm fruit flour

\begin{tabular}{lccc}
\hline Parameter & $\begin{array}{c}\text { Freeze- } \\
\text { dried flour }\end{array}$ & $\begin{array}{c}\text { Oven dried } \\
\text { flour }\end{array}$ & $\begin{array}{c}\text { Solar dried } \\
\text { flour }\end{array}$ \\
\hline LBD $(\mathrm{g} / \mathrm{mL})$ & $0.36 \pm$ & $0.63 \pm$ & $0.54 \pm$ \\
& $0.00^{\mathrm{a}}$ & $0.00^{\mathrm{b}}$ & $0.00^{\mathrm{c}}$ \\
TBD $(\mathrm{g} / \mathrm{mL})$ & $0.46 \pm$ & $0.77 \pm$ & $0.64 \pm$ \\
& $0.00^{\mathrm{a}}$ & $0.00^{\mathrm{b}}$ & $0.00^{\mathrm{c}}$ \\
Hausner Ratio & $1.27 \pm$ & $1.23 \pm$ & $1.19 \pm$ \\
Carr's Index & $0.00^{\mathrm{a}}$ & $0.00^{\mathrm{b}}$ & $0.00^{\mathrm{b}}$ \\
(\%) & $21.43 \pm$ & $18.75 \pm$ & $15.79 \pm$ \\
\hline
\end{tabular}

Values represent mean $\pm \mathrm{SD}$ of at least three replicates. Means in the same row with the same superscript are not significantly different $(\mathrm{p}>0.05)$. TBD $=$ Tapped Bulk Density; LBD $=$ Loose Bulk Density

\section{Conclusion}

The African palmyra palm (Borassus aethiopum) fruit flour (APP) had considerably high amounts of crude fibre, available carbohydrate, and metabolic energy. The high fibre content of APP can be explored in the production of lower glycaemic index, hypolipidemic and prebiotic foods. The relatively high swelling power, water and oil absorption capacities (WAC/OAC) also implies the APP flour could be widely applied in the pastry industry as a thickener, binder, stabilizer, humectant and flavor-retaining agent. The flour can be applied in the production of bread, cookies, cakes, pasta and food gels due to its high swelling power and water absorption capacity. The low foaming capacity also makes the APP flour a potential ingredient in the biscuit industry as well as in the production of crackers. Drying had a significant effect on the APP flour samples especially on the energy content, WAC, OAC, bulk densities and Carr's Index (compressibility index). There was, however, less variation among the ash, crude fibre, crude protein, non-fibre carbohydrates, swelling power, solubility, foaming capacity and Hausner Ratio of the oven dried and solar dried flours. The drying method had 
no significant effect on the total soluble solid content of the African palmyra palm (Borassus aethiopum) fruit flours. Overall, oven drying method presents the best option considering the drying time, quality and cost factors.

\section{References}

Adams, M.L., Lombi, E., Zhao, F.J. and McGrath, S.P. (2002). Evidence of low selenium concentrations in UK bread-making wheat grain. Journal of the Science of Food and Agriculture, 82, 1160-1165. https://doi.org/10.1002/jsfa.1167

Adebowale, A.A., Sanni, S.A. and Koleoso, Y.S. (2011). Chemical and functional qualities of high quality cassava flour from different SMEs in Nigeria. African Journal of Root and Tuber Crops, 9(1), 1116.

Adzinyo, O.A., Kpodo, F.M., Asimah, V.K. and AsanteDornyinah, D. (2015). Sensory and physicochemical characteristics of naturally flavoured Borassus aethiopum syrups. Food Science and Quality Management, 45, 109-113.

Akpata, M.I. and Akubor, P.I. (1999). Chemical composition and selected functional properties of sweet orange (Citrus sinensis) seed flour. Journal of Plant Food for Human Nutrition, 54, 353-362. https://doi.org/10.1023/A:1008153228280

Akpapunam, M.A. and Sefa-Dedeh, S. (1997). Jack bean (Canavalia ensiformis) nutrition related, aspects and needed nutrition research. Journal of Plant Food for Human Nutrition, 10, 123-127. https:// doi.org/10.1007/BF02436029

Ali, A., Alhadji, D., Tchiegang, C. and Saïdou, C. (2010). Physico-chemical properties of palmyra palm (Borassus aethiopum Mart.) fruits from Northern Cameroon. African Journal of Food Science, 4(3), 115-119.

AOAC. (1990). Official Methods of Analysis. Association Official Analysis Chemists. $15^{\text {th }}$ ed. Washington D.C.: AOAC

Apea-Bah, F.B., Oduro, I., Ellis, W.O. and SafoKantanka, O. (2011). Factor analysis and age at harvest effect on the quality of flour from four cassava varieties. World Journal of Dairy and Food Sciences, 6, 43-54.

Appiah, F., Asibuo, J.Y. and Kumah, P. (2011). Physical and functional properties of bean flours of three cowpea (Vigna unguiculata L.) varieties in Ghana. African Journal of Food Science, 5(2), 100-104.

Atuonwu, A.C. and Akobundu, E.N. (2010). Functional and pasting properties of pumpkin (Cucurbita pepo).
Journal of Agricultural and Veterinary Science, 2, 36-49.

Barbosa-Canovas, G.V., Ortega-Rivas, E., Juliano, P. and Yan, H. (2005). Food powders: physical properties, processing and functionality, p. 71-74. London: Kluwer Academic Publishers.

Borja, J.C.S., Sedano, D.S. and Noel, M.G. (2013). Functional properties of flours prepared from glucosinolate-rich vegetables: alugbati (Basella rubra). Research Congress 2013, De La Salle University Manila, March 7-9, 2013. Manilla: DLSU.

Chandra, S. and Samsher, S. (2013). Assessment of functional properties of different flours. African Journal of Agricultural Research, 8(38), 4849-4852.

Di Scala, K. and Crapiste, G. (2008). Drying kinetics and quality changes during drying of red pepper. $L W T$ Food Science and Technology, 41(5), 789-795. https://doi.org/10.1016/j.lwt.2007.06.007

Dossou, V.M., Agbenorhevi, J.K., Alemawor, F. and Oduro. I. (2014). Physicochemical and functional properties of different ackee (Blighia sapida) aril flours. American Journal of Food Science and Technology, 2(6), 187-191. https://doi.org/10.12691/ ajfst-2-6-3

Dziedzoave, N.T., Abass, A.B., Amoa-Awua, W.K.A. and Sablah M. (2006). In Adegoke, G.O. and Brimer, L. (Eds.) Quality management manual for production of high quality cassava flour. Ibadan, Nigeria: International Institute of Tropical Agriculture.

Eleazu, O.C., Eleazu, K.C. and Kolawole, S. (2014). Use of indigenous technology for the production of high quality cassava flour with similar food qualities as wheat flour. Acta Scientarium Polonorum. Technologia Alimentaria. 13(3), 249-256. https:// doi.org/10.17306/J.AFS.2014.3.3

Eriksson, E. (2013). Flour from three local varieties of Cassava (Manihot esculenta Crantz): physicochemical properties, bread making quality and sensory evaluation. Sweden: Sveriges lantbruksuniversitet, Institutionen för livsmedelsvetenskap, BSc. Thesis

Eshun, G. (2012). Nutrient composition and functional properties of bean flours of three soya bean varieties from Ghana. African Journal of Food Science and Technology, 3(8), 176-181.

Ezeocha, V.C. and Ojimelukwe, P.C. (2012). The impact of cooking on the proximate composition and antinutritional factors of water yam (Dioscorea alata). Journal of Stored Products and Postharvest Research, 3(13), 172-176. 
Ezeokeke, C.T. and Onuoha, A.B. (2016). Nutrient composition of cereal (maize), legume (soybean) and fruit (banana) as a complementary food for older infants and their sensory assessment. Journal of Food Science and Engineering, 6, 139-148.

Fennema, O.R. (1996). Food Chemistry, p. 245-370. New York: Marcel Dekker Inc.

Hassan, L.G. and Umar, K.J. (2004). Proximate and mineral composition of seeds and pulp of African locust bean (Parkia biglobosa L.). Nigerian Journal of Basic and Applied Sciences, 13, 15-27.

Heshe, G.G., Haki, G.D. and Woldegiorgis, A.Z. (2015). Effect of refined milling on the nutritional value and antioxidant capacity of wheat types common in Ethiopia and a recovery attempt with bran supplementation in bread. Journal of Food Processing and Technology, 6(11), 506-514.

Lombor, T.T., Olaitan, I.N. and Ede, R.A. (2014). Proximate composition, antinutrient content and functional properties of soursop flour as influenced by oven and freeze-drying methods. Current Research in Nutrition and Food Science, 2(2), 106110. https://doi.org/10.12944/CRNFSJ.2.2.08

Krokida, M.K. and Maroulis, Z.B. (1997). Effect of drying method on shrinkage and porosity. Drying Technology, 15(10), 2441-2458. https:// doi.org/10.1080/07373939708917369

Leach, H.W., McCowen, L.D. and Scoch, T.J. (1959). Structure of starch granule Swelling and solubility patterns of various starches. Cereal Chemistry, 36, 534-544.

Maziya -Dixon, B., Adebowale, A.A., Onabanjo, O.O. and Dixon, A.G.O. (2015). Effect of variety and drying methods on physico-chemical properties of high quality cassava flour from yellow cassava roots. African Crop Science Conference Proceeding, 7, 635 $-641$.

Mehta, K. and Kaur, A. (1992). Reviews: dietary fibre. International Journal of Diabetes in Developing Countries, 12, 12-18.

Mepba, H.D., Eboh, L. and Nwaojigwa, S.U. (2007). Chemical composition, functional and baking properties of wheat-plantain composite flours. African Journal of Food Agriculture and Development, 7(1), 1-22.

Morris, M.L., Tripp, R. and Dankyi. A.A. (1999). Adoption and impacts of improved maize production technology: a case study of the Ghana grains development project economics program, p. 99-101. Mexico: CIMMYT

Mohammed, A., Dangoggo, S.M., Tsafe, A.I., Itodo, A.U. and Atiku, F.A. (2011). Proximate, minerals and anti-nutritional factors of Gardenia agualla (Gauden dutse). Journal of Chemical Society of Nigeria, 10(6), 577-581.

Muazu, J., Musa, H., Isah, A.B., Bhatia, P.G. and Tom, G.M. (2011). Extraction and characterization of kaffir potato starch: A potential source of pharmaceutical raw material. Journal of Natural. Product Plant Resources, 1(2), 41-49.

N'guessan, Y.D., Bedikou, M.E., Zoue, L.T., Goualie, B.G. and Niamke, S.L. (2014). Physicochemical, nutritive and safety evaluation of local cereal flours sold in areas of the District of Abidjan-Côte d'Ivoire. Journal of Applied Biosciences, 83, 7579-7594. https://doi.org/10.4314/jab.v83i1.8

Nielsen, S.S. (2010). Food Analysis. $4^{\text {th }}$ ed. USA: Springer Science + Business Media. https:// doi.org/10.1007/978-1-4419-1478-1

Ogunsina, B.S., Radha, C. and Govardhan-Singh, R.S. (2010). Physicochemical and functional properties of full-fat and defatted Moringa oleifera kernel flour. International Journal of Food Science and Technology, 45(11), 2433-2439. https:// doi.org/10.1111/j.1365-2621.2010.02423.x

Oppong, D., Arthur, E., Kwadwo, S.O., Badu, E. and Sakyi, P. (2015). Proximate composition and some functional properties of soft wheat flour. International Journal of Innovative Research in Science, Engineering and Technology, 4(2), 753758.

Ouinsavi, C., Gbémavo, C. and Sokpon, N. (2011). Ecological structure and fruit production of African fan palm (Borassus aethiopum) populations. American Journal of Plant Sciences, 2, 733-743. https://doi.org/10.4236/ajps.2011.26088

Pereira, M.A. (2004). Dietary fiber and risk of coronary heart disease: a pooled analysis of cohort studies. Archives of Internal Medicine, 164, 370-376. https:// doi.org/10.1001/archinte.164.4.370

Rahman, M.S. (2005). Dried food properties: challenges ahead. Drying Technology, 23(4), 695-715. https:// doi.org/10.1081/DRT-200054176

Sambou, B., Lawesson, J.E. and Barfod, A.S. (1992). Borassus aethiopum, a threatened multipurpose palm in Senegal. Principles, 36(3), 148-155.

Senanayake, S.A., Ranaweera, K.K.D., Bamunuarachchi, A. and Gunaratne, A. (2012). Proximate analysis and phytochemical and mineral constituents in four cultivars of yams and tuber crops in Sri Lanka. Tropical Agricultural Research and Extension, 15(1), 32-36. https://doi.org/10.4038/ tare.v15i1.5240

Siaw, D.E.K.A., Asamoah, E.F. and Baidoe, G.A. 
(2014). The stock and socio-economic uses of Borassus aethiopum in Abrimasu forest reserve of Mampong forest district. Journal of Energy and Natural Resource Management (JENRM), 1(3), 148155. https://doi.org/10.26796/jenrm.v1i2.32

Udensi, E.A., Oselebe, H.O. and Iweala, O.O. (2008). The investigation of chemical composition and functional properties of water yam (Dioscorea alata): effect of varietal differences. Pakistan Journal of Nutrition, 7(2), 342-344. https:// doi.org/10.3923/pjn.2008.342.344

Umar, K.J., Abdullahi, B.M., Muhammad, B., Muhammad, S., Hassan, L.G. and Sani, N.A. (2015). Nutritional and antinutritional profile of Borassus aethiopum mart (African palmyra palm) shoots. International Journal of Sciences: Basic and Applied Research, 24(3), 39-49.

Wijesinghe, J.A.A.C., Wicramasinghe, I. and Saranandha, K.H. (2015). Kithul flour (Caryota urens) as a potential flour source for food industry. American Journal of Food Science and Technology, 3(1), 10-18.

Wiriya, P., Paiboon, T. and Somchart, S. (2009). Effect of drying air temperature and chemical pretreatments on quality of dried chili. International Food Research Journal, 16, 441-454.

Wong, J.M.W., de Souza, R., Kendall, C.W.C., Emam, A. and Jenkins, D.J.A. (2006). Colonic health: fermentation and short chain fatty acids. Journal of Clinical Gastroenterology, 40(3), 235-243. https:// doi.org/10.1097/00004836-200603000-00015

Yellavila, S.B., Agbenorhevi, J.K., Asibuo, J.Y. and Sampson, G.O. (2015). Proximate composition, minerals content and functional properties of five lima bean accessions. Journal of Food Security, 3(3), 69-74 